\title{
Korelasi Antara Penerapan Akad Mudharabah dan Profitabilitas Pada Bank Syariah Mandiri (Tahun 2012-2016)
}

\author{
Nuraini \& Azhar Muttaqin \\ Program Studi Ekonomi Syariah, \\ Fakultas Agama Islam, Universitas Muhammadiyah Malang \\ E-mail: nurainy595@gmail.com
}

\begin{abstract}
This research aims to know the correlation between implementation of mudharabah and the profitability in the Bank Syari'ah Mandiri. Quantitative approach was used in this research with Bank Syari'ah Mandiri as the subject. The research based on mudharabah development in Bank Syariah Mandiri, and it was observed from the data of financial statements that have been published in 2012 to 2016. The method is collecting data from Bank Syariah Mandiri financial statements in 2012 to 2016 and observing the data. Independent variable in this research is mudharabah and its dependent variable is profitability. The statistical method of data analysis used is a simple regression. The result showed that mudharabah as independent variable has correlation with profitability as dependent variable. It could be seen from the significant value which is $0,023<0,05$. Based on the significant value of the coefficient table can be said that mudharabah has a correlation with profitability positively and significantly, which is $0.023<0.05$.
\end{abstract}

Keywords: Mudharabah, Profitabilitas (ROA), Bank Syariah Mandiri.

\section{Pendahuluan}

Perbankan syariah di Indonesia telah mengalami perkembangan dengan pesat, masyarakat mulai mengenal dengan apa yang disebut Bank Syariah, dengan diawali berdirinya pada tahun 1992 oleh bank yang diberi nama dengan Bank Muamalat Indonesia (BMI), sebagai pelopor berdirinya perbankan yang berlandaskan sistem syariah, kini Bank Syariah yang tadinya diragukan akan sistem operasionalnya, telah menunjukkan angka kemajuan yang sangat baik. Menurut Pasal 1 Undang-Undang No. 21 Tahun 2008. Bank adalah badan usaha yang menghimpun dana masyarakat dalam bentuk simpanan dan menyalurkannya

Vol. 3, No.1, Agustus 2018 
kepada masyarakat dalam bentuk kredit dan atau dalam bentuk-bentuk lainnya dalam rangka meningkatkan taraf hidup rakyat banyak. Sedangkan menurut pasal 1 Undang-Undang No. 4 Tahun 2003 tentang Perbankan, Bank adalah Bank Umum dan Bank Perkreditan Rakyat yang melaksanakan kegiatan usaha secara konvensional atau berdasarkan prinsip syariah yang dalam kegiatannya tidak memberikan jasa dalam lalu lintas pembayaran. Bank syariah adalah bank yang dalam aktivitasnya, baik penghimpunan dana maupun penyaluran dana memberikan imbalan atas dasar prinsip syariah, yaitu bagi hasil dan jual beli. ${ }^{1}$

Produk-produk yang ditawarkan oleh bank syariah, menurut mereka hanyalah produk-produk bank konvensional yang dipoles dengan penerapan akad-akad yang berkaitan dengan syariah. Alasannya karena sistem bagi hasil dalam prakteknya masih menyerupai sistem bunga bagi bank konvensional. Begitu pula penyaluran dana Bank Syariah yang lebih besar bertumpu pada pembiayaan murabahah, yang mengambil keuntungan berdasarkan margin, dianggap oleh masyarakat hanyalah sekedar polesan dari cara pengambilan bunga pada bank konvensional. Menurut mereka masih sangat sulit untuk membedakan antara bagi hasil, laba dan bunga bank konvensional. Kalaupun bisa hanyalah pada tataran teorinya saja, sedang prakteknya masih terlihat rancu untuk membedakan bagi hasil, margin dan bunga.

Meski secara teoritis sistem bagi hasil dengan akad mudharabah dan musyarakah sangat baik, namun yang terjadi pembiayaan perbankan syariah dengan pola tersebut belum menjadi barometer bank syariah, sehingga perbandingannya cukup kecil jika dibandingkan dengan pembiayaan dengan pendapatan tetap. Hal tersebut lebih disebabkan pada tuntutan yang harus dipenuhi oleh bank syariah yang mengikuti struktur bank komersial. Sehingga pembiayaan dengan basis pendapatan tetap cenderung menjadi pilihan bagi bank syariah. ${ }^{2}$ Prinsip bagi hasil merupakan karakteristik umum dan landasan dasar bagi operasional bank syariah secara keseluruhan. Secara syariah prinsip berdasarkan pada kaidah mudharabah akan berfungsi sebagai mitra baik dengan penabung demikian juga dengan pengusaha yang meminjam dana. Dalam operasional Bank Syariah, mudharabah merupakan salah satu bentuk akad pembiayaan yang akan diberikan kepada nasabahnya.

Bank Syariah merupakan lembaga keuangan yang berfungsi memperlancar mekanisme ekonomi di sektor riil melalui aktivitas kegiatan usaha (investasi, jual beli, atau lainnya) berdasarkan prinsip syariah, yaitu aturan perjanjian berdasarkan hukum Islam antara bank dan pihak lain untuk penyimpanan dana dan atau pembiayaan kegiatan usaha, atau kegiatan lainnya yang dinyatakan sesuai dengan nilai-nilai syariah yang bersifat makro maupun mikro.

${ }^{1}$ Ade Arthesa dan Edia Handima, Bank dan Lemabaga Keuangan Bukan Bank (Jakarta: PT. Indeks, 2006), hal 62.

${ }^{2}$ Muhammad, Teknik Perhitungan Bagi hasil di Bank Syariah (Yogyakarta: UII Press, 2001), hal 214. 
Bank Syariah Mandiri merupakan salah satu bank yang menggunakan prinsip syariah dalam menjalankan kegiatan usahanya. Sama seperti perusahaan lainnya, tujuan berdirinya Bank Syariah Mandiri adalah untuk memperoleh keuntungan. Memperoleh keuntungan merupakan tujuan utama dari berdirinya suatu perusahaan atau badan usaha, baik yang berbentuk Perseroan Terbatas (PT), yayasan ataupun bentuk-bentuk badan usaha lainnya. Kemudian yang lebih penting lagi apabila suatu badan usaha terus-menerus memperoleh keuntungan maka berarti kelangsungan hidup badan tersebut akan terjamin. ${ }^{3}$

Bank dapat memperoleh keuntungan berasal dari selisih dana yang terhimpun dari masyarakat dan dana yang disalurkan kepada masyarakat yang berupa kredit atau pembiayaan atau bentuk-bentuk lainnya. Perbankan yang berdasarkan prinsip konvensional diperoleh dari selisih bunga simpanan yang diberikan kepada penyimpan dengan bunga pinjaman atau kredit yang disalurkan. Yang menjadi perbedaan antara kredit yang diberikan oleh bank berdasarkan konvensional dengan pembiayaan yang diberikan oleh bank berdasarkan prinsip syariah adalah terletak pada keuntungan yang diharapkan. Bagi bank berdasarkan prinsip konvensional keuntungan yang diperoleh melalui bunga sedangkan bagi bank syariah berdasarkan prinsip bagi hasil berupa imbalan atau bagi hasil. ${ }^{4}$

Pemberian pinjaman yang berdasarkan bunga berakibat pada penerimaan pinjaman yang harus menanggung resiko yang telah ditetapkan dimuka. Perjanjian yang demikian itu dianggap tidak adil dan bertentangan dengan nilai-nilai Islam. Menurut Umar Chapra, dalam sebuah ekonomi dimana perbedaan kekayaan adalah substansial dan pemberi pinjaman ingin memperoleh keuntungan tanpa harus menanggung resiko usaha, adalah tidak rasional baginya. ${ }^{5}$

Berbeda dengan bank syariah yang berpegang pada prinsip keadilan, dimana keuntungan atau kerugian akan ditanggung bersama. Jika kita melihat mode pembiayaan dalam perbankan syariah digolongkan pada beberapa golongan. Diantaranya menurut Umer Chapra adalah mode primer, seperti: mudharabah dan musyarakah dan mode sekunder seperti: murabahah, ijarah, ijarah waiqtina, salam dan istisna. ${ }^{6}$

Pada pembiayaan yang menggunakan mode-mode primer pihak bank mendapatkan keuntungan dari sistem bagi hasil (profit and loss sharing) dan mempunyai tingkat resiko yang besar karena melibatkan bagi untung dan rugi. Sedangkan pada pembiayaan yang menggunakan mode skunder, pihak bank mendapatkan margin keuntungan kembalian positif yang ditentukan di depan. Pada prinsipnya bagi hasil melibatkan mode-mode primer didasarkan pada penyertaan modal sendiri dan relatif lebih beresiko karena melibatkan bagi untung

\footnotetext{
${ }^{3}$ Kasmir, Manajemen Perbankan (Jakarta: Raja Grafindo Persada, 2002), hal 34.

${ }^{4}$ Ibid., Kasmir, Manajemen Perbankan ..., hal.93.

5 M. Umar Chapra, Islam dan Tantangan, Ekonomi Islamisasi Kontemporer, (Jakarta: Gema Insani, 2005), hal. 352.

${ }^{6}$ Ibid., M. Umar Chapra, Masa Depan Ilmu Ekonomi: ...., hal 223.
} 
dan rugi, tingkat keuntungan tidak dinyatakan di depan dan dapat menjadi positif atau negatif tergantung pada hasil akhir usaha, mode-mode primer ini dikenal dengan pembiayaan mudharabah dan musyarakah. ${ }^{7}$

Bank Syariah Mandiri memiliki banyak produk dalam pembiayaannya, di antaranya adalah dalam bentuk mode primer yaitu pembiayaan mudharabah dan musyarakah, serta mode sekunder dalam bentuk pembiayaan murabahah. Mudharabah adalah akad kerjasama usaha antara dua pihak dimana pemilik modal menyediakan dana $100 \%$ dan pengelola usaha sebagai pengelola usaha dengan nisbah bagi hasil menurut kesepakatan di muka, dan musyarakah adalah akad kerjasama diantara pemilik modal yang mencampurkan modal mereka untuk tujuan mencapai keuntungan. ${ }^{8}$ Sedangkan murabahah merupakan akad jual beli barang dengan menyatakan harga perolehan dan keuntungan yang disepakati oleh penjual dan pembeli. Untuk mengukur kemampuan bank dalam memperoleh laba secara keseluruhan dan tingkat efisiensi usaha, baik dari kegiatan operasional maupun non operasional digunakan Profitabilitas. Profitabilitas Rerurn on asset adalah rasio yang digunakan untuk mengetahui kemampuan perusahaan untuk memperoleh keuntungan.

Oleh karena itu, tingginya minat nasabah untuk melakukan akad pada pembiayaan mudharabah di Bank Syariah, tentunya akan memberikan kontribusi yang besar bagi pendapatan bank syariah. Dari pendapatan-pendapatan tersebut kiranya bank dapat mengetahui seberapa besar profit yang dihasilkan bank syariah atas terlaksanya pembiayaan mudharabah tersebut. Dari latar belakang di atas, peneliti tertarik untuk melakukan penelitian lebih lanjut dengan judul: "Korelasi Antara Pelaksanaan Mudharabah Dengan Profitabilitas Pada Bank Syariah Mandiri”.

\section{Bank Syariah}

Bank syariah, yaitu bank yang dalam aktivitasnya, baik penghimpunan dana maupun dalam penyaluran dananya memberikan dan memakai imbalan atas dasar prinsip syariah yaitu jual beli dan bagi hasil. Bank pada dasarnya merupakan perusahaan atau lembaga perantara keuangan (financial intermediary) yaitu antara pihak yang kelebihan dana dengan pihak yang kekurangan dana. Sebagai lembaga perantara bank harus menyalurkan dana yang dikumpulkan dari masyarakat tersebut kepada pihak-pihak yang membutuhkan dana dalam bentuk pinjaman atau yang lebih dikenal dengan kredit di Bank Konvensional atau pembiayaan di Bank Syariah. Pengalokasian dana dapat pula dilakukan dengan membelikan berbagai asset yang dianggap menguntungkan bank. ${ }^{9}$

\footnotetext{
${ }^{7}$ Ibid, hal 225.

${ }^{8}$ Acarya, Akad \& Produk Bank Syariah, (Jakarta: PT Raja Grafindo Persada, 2007), hal 60.

9 Sigit Triandaru dan Totok Budisantoso, Bank dan Lembaga Keuangan Lain. (II, Jakarta: Salemba Empat, 2006), hal 50
} 
Prinsip syariah adalah aturan perjanjian berdasarkan hukum Islam antara bank dan pihak lain untuk penyimpanan dana dan atau pembiayaan kegiatan usaha, atau kegiatan lainnya yang dinyatakan sesuai dengan syariah, antara lain pembiayaan berdasarkan prinsip bagi hasil (mudharabah), pembiayaan berdasarkan prinsip penyertaan modal (musyarakah), prinsip jual beli barang dengan memperoleh keuntungan (murabahah), atau pembiayaan barang modal berdasarkan prinsip sewa murni tanpa pilihan (ijarah) atau dengan adanya pilihan pemindahan kepemilikan atas barang yang disewa dari pihak bank oleh pihak lain. ${ }^{10}$

\section{Mudharabah dan Implementasinya}

Mudharabah berasal dari kata dharaba yang berarti memukul atau berjalan. Definisi memukul atau berjalan ini maksudnya adalah proses seseorang memukulkan kakinya dalam menjalankan usaha. ${ }^{11}$ Mudharabah atau qiradh termasuk dalam kategori syirkah atau kerjasama dengan cara sistem bagi hasil. Dalam Al-Qur'an kata mudharabah tidak disebutkan secara jelas dengan istilah mudharabah. Al-Qur'an hanya menyebutkannya secara musytaq dari kata dharabah yang diulang sebanyak 58 kali. Secara istilah, Mudharabah adalah akad kerja sama antara pemilik modal dengan yang mempunyai keahlian atau keterampilan untuk mengelola suatu usaha yang produktif dan halal. Hasil dari penggunaan dana tersebut dibagi bersama berdasarkan nisbah yang disepakati, jika terjadi kerugian ditanggung pemilik modal. ${ }^{12}$

Mudharabah dalam perspektif fiqih merupakan kontrak yang melibatkan antara dua kelompok, yaitu pemilik modal yang mempercayakan modalnya kepada pengelola untuk digunakan dalam aktifitas perdagangan. Sedangkan keuntungan dagang itu dibagi menurut kesepakatan bersama. pengelola dalam hal ini memberikan kontribusi pekerjaan, waktu dan mengelola usahanya sesuai dengan ketentuan yang dicapai dalam kontrak, salah satunya untuk mencapai keuntungan yang dibagi antara pihak investor dan pengelola berdasarkan proporsi yang telah disetuju bersama. Namun apabila terjadi kerugian yang menanggung adalah pihak investor saja. ${ }^{13}$ Menurut ulama Hanafiyah, mudharabah adalah memandang tujuan dari pihak yang berakad yang berserikat dalam keuntungan karena harta diserahkan kepada yang lain dan yang lain punya jasa mengelola harta itu. Maka mudharabah adalah akad Syirkah dalam laba, satu pihak pemilik harta dan pihak lain pemilik jasa. Ulama Malikiyah berpendapat bahwa mudharabah ialah akad perwalian, dimana pemilik harta mengeluarkan hartanya kepada yang lain untuk diperdagangkan dengan pembayaran yang ditentukan (emas dan perak). Imam Hanabilah berpendapat bahwa mudharabah ialah ibarat pemilik harta

10 Wiroso, Penghimpunan Dan dan Distribusi Hasil Usaha Bank Syariah. (Jakarta: PT. Grafindo, 2005), hal 98.

${ }^{11}$ Muhammad Syafi'I Antonio, Bank Syariah dari Teori ke Praktik, (Jakarta: Gema Insani Press, 2001), hal 95.

12 Nurul Huda dan Mohamad Heykal, Lembaga Keuangan Islam: Tinjauan Teoretis dan Praktis, (1, Jakarta: Kencana, 2010), hal. 71-72.

13 Abdullah Saeed, Bank Islam dan Bunga, (Yogyakarta: Pustaka Pelajar, 2004), hal 91. 
menyerahkan hartanya dengan ukuran tertentu kepada orang yang berdagang dengan bagian dari keuntungan yang diketahui. Sementara itu, Ulama Syafi'iyah berpendapat bahwa mudharabah ialah akad yang menentukan seseorang menyerahkan hartanya kepada yang lain untuk ditijarahkan. Lebih lanjut Wahbah Zuhaili berpendapat, mudharabah adalah akad penyerahan modal oleh si pemilik kepada pengelola untuk diperdagangkan dan keuntungan dimiliki bersama antara keduanya sesuai dengan persyaratan yang mereka buat. Menurut Sayid Sabiq sebagaimana dikutip oleh Ahmad Wardi, mengatakan bahwa yang dimaksud dengan mudharabah adalah suatu akad antara dua pihak dimana salah satu pihak memberikan uang (modal) kepada pihak lain untuk diperdagangkan dengan ketentuan bahwa keuntungan dibagi diantara mereka berdua sesuai dengan kesepakatan mereka.

Dari definisi tersebut dapat dipahami bahwa mudharabah adalah suatu akad atau perjanjian antara dua orang atau lebih, dimana pihak pertama memberikan modal usaha, sedangkan pihak lain menyediakan tenaga dan keahlian dengan ketentuan bahwa keuntungan dibagi diantara mereka sesuai dengan kesepakatan yang mereka tetapkan bersama. Dengan kata lain dapat dikemukakan bahwa mudharabah adalah kerja sama antara harta dengan tenaga atau keahlian. Dengan demikian, dalam akad mudharabah ada unsur syirkah atau kerja sama, hanya saja bukan kerja sama harta dengan harta ataupun tenaga dengan tenaga, melainkan antara harta dengan tenaga. Disamping itu, juga terdapat unsur syirkah (kepemilikan bersama) dalam keuntungan. Namun apabila terjadi kerugian maka kerugian tersebut ditanggung oleh pemilik modal, sedangkan pengelola tidak dibebani kerugian, karena ia telah rugi waktu, fikiran dan tenaga. ${ }^{14}$

Mudharabah di perbankan biasa diterapkan pada produk-produk pembiayaan dan pendanaan. Pada sisi penghimpunan dana, mudharabah diterapkan pada:

a) Tabungan berjangka, yaitu tabungan yang dimaksudkan untuk tujuan khusus, seperti tabungan haji, tabungan qurban dan deposito biasa.

b) Deposito spesial dimana dana di titipkan nasabah untuk bisnis tertentu, misalnya murabahah atau ijarah.

Adapaun pada sisi pembiayaan, mudharabah diterapkan untuk:

a) Pembiayaan modal kerja, seperti modal untuk perdagangan dan jasa.

b) Investasi khusus juga disebut mudharabah muqayyadah, dimana sumber dana khusus dan penyaluran khusus dengan syarat yang telah diterapkan oleh pemilik modal.

Dalam rangka menghimpun dana dari masyarakat, produk mudharabah dapat berupa:

a) Simpanan Mudharabah

Modal yang terima dari nasabah akan diinvestasikan oleh bank dengan proporsi keuntungan yang telah disepakati dalam modal mudharabah, seperti sepertiga atau seperempatnya akan disimpan di bank dan sisanya akan dibayarkan kepada nasabah. Jika bank mengalami kerugian setiap nasabah ikut bertanggung jawab atas kerugian tersebut sesuai dengan proporsi modal yang ditanamnya. Bentuk

\footnotetext{
${ }^{14}$ Hasan M Ali, Marketing. (Jakarta: PT Buku Kita, 2008), hal 170.
} 
simpanan ini bisa berupa tabungan berjangka, yaitu tabungan yang dimaksud untuk tujuan khusus seperti tabungan haji, tabungan qurban dan deposito.

b) Titipan

Bank dapat menerima titipan dari masyarakat dengan mengkombinasikan produk al-Wadiah yad adh-dhamanah dengan mudharabah sehingga pihak penitip dapat mendapatkan keuntungan dari penggunakan dana titpan tersebut oleh pihak bank dengan proporsi yang telah disepakati bersama. Sebagai suatu titipan, pihak bank bertanggung jawab untuk mengembalikan dana titipan tersebut kepada nasabah. Adapun dalam kegiatan penyaluran dana kepada masyarakat, mudharabah dipraktikan dalam bentuk:

a) Pembiayaan modal kerja, seperti modal berdagang dan jasa.

b) Investasi khusus disebut juga disebut mudharabah muqayyadah, dimana sumber dana khusus dan penyaluran yang khusus dengan syarat-syarat yang telah diterapkan oleh pemilik modal. ${ }^{15}$

\section{Profitabilitas dan Indikator Pengukurannya}

Rasio profitabilitas adalah alat untuk mengukur keefektifan dan kesuksesan manajemen dalam menghasilkan suatu laba dalam periode tertentu. Profitabilitas suatu bank dapat di ketahui dengan menganalisis laporan keuangannya, dan dari hasil analisis tersebut akan dapat tercermin kemampuan bank dalam memperoleh laba. Profitabilitas adalah perbandingan laba setelah pajak dengan modal inti atau laba sebelum pajak dengan total aset yang dimiliki bank pada periode tertentu. Agar hasil perhitungan rasio mendekati pada kondisi yang sebenarnya, maka posisi modal atau aset dihitung secara rata-rata selama periode tersebut. ${ }^{16}$

Menurut Van Horne dan Wac Howicz mengemukan rasio profitabilitas terdiri dari dua jenis, yaitu rasio yang menunjukkan profitabilitas dalam kaitannya dengan penjualan dan rasio profitabilitas yang menunjukkan dengan investasi. Profitabilitas dala hubungannya dengan penjualan terdiri atas margin laba kotor dan margin laba bersih. Profitabilitas dalam hubungannya dengan investasi terdiri atas tingkat pengembalian atas aktiva dan pengembalian atas ekuitas. Sedangkan menurut Weygandt, rasio profitabilitas adalah rasio yang digunakan untuk mengukur efektivitas manajemen perusahaan secara keseluruhan, yang ditunjukkan dengan besarnya laba yang diperoleh perusahaan. Rasio profitabilitas dianggap sebagai alat yang paling valid dalam mengukur hasil pelaksanaan operasi perusahaan, karena rasio profitabilitas merupakan alat pembanding pada berbagai alternatif investasi yang sesuai dengan tingkat risiko. Semakin besar risiko investasi, diharapkan profitabilitas yang diperoleh semakin tinggi pula. Tujuan analisis profitabilitas sebuah bank adalah untuk mengukur tingkat efisiensi usaha dan profitabilitas yang dicapai oleh bank yang bersangkutan.

Kinerja keuangan perusahaan dari sisi manajemen, mengharapkan laba bersih sebelum pajak yang tinggi karena semakin tinggi laba perusahaan semakin

15 Neneng Nurhasanah, mudharabah dalam Teori dana Praktik, (Bandung: PT. Refika Aditama, 2015), hal 111-113.

${ }^{16}$ Rizal Yaya, Aji Erlangga Martawireja, Ahim Abdurahim, Akutansi Perbankan Syariah Dari Teori ke Praktik Kontemporer, (Jakarta: Salemba Empat, 2014), hal 107. 
fleksibel perusahaan dalam menjalankan aktivitas operasional perusahaan. Sehingga laba sebelum pajak (EBT) perusahaan akan meningkat bila kinerja keuangan perusahaan meningkat. Laba sebelum pajak adalah laba bersih dari kegiatan operasional sebelum pajak. Sedangkan rata-rata total aset merupakan rata-rata volume usaha atau aktiva. ${ }^{17}$ Rasio yang melihat kemampuan perusahaan menghasilkan laba (profitabilitas). Rasio profitabilitas terdiri dari profit margin, return on asset dan return on equity. Selengkapnya sebagai berikut:

- Profit Margin =Laba Bersih/Penjualan

- Return On Asset (ROA)=Laba Bersih/Total Aktiva

- Return On Equity (ROE)=Laba Bersih/Modal Sendiri (Saham)

Studi yang menggunakan rasio keuangan di atas mulai dilakukan pada tahun 1930-an. Kemudian beberapa studi lanjutan lebih berfokus pada kebangkrutan usaha. Kebanyakan hasil penelitian tersebut meyakini bahwa perusahaan yang bangkrut memiliki rasio yang berbeda dari perusahaan yang tidak bangkrut. Oleh karena itu, analisis rasio tersebut sangat bermafaat untuk membaca laporan keuangan. ${ }^{18}$ Laporan keuangan persentatif sebanding (comoon-size statement) merupakan salah satu metode analisis yang manfaat fungsionalnya sangat besar karena pos-pos laporan keuangan ditempatkan dalam perspektif. Laporan keuangan persentatif sebanding secara sederhana menyajikan laporan laba-rugi dan neraca sebagai persentase dari pos (unsur) sebanding tentu yang dapat diambil dari bisni yang serupa atau dapat juga berupa total penerimaan, total biaya perusahaan yang bersangkutan. Secara matematis rumus sederhananya adalah:

$$
\begin{aligned}
& \text { Laba } \\
& (\text { Profit })
\end{aligned}=\begin{array}{cc}
\text { Total Penerimaan } \\
(\text { Total Revineu })
\end{array} \quad \begin{gathered}
- \text { Total Biaya } \\
(\text { Total Cost })
\end{gathered}
$$

Laba merupakan keuntungan atau pendapatan bersih yang diperoleh perusahaan selama satu kali proses produksi. Total penerimaan merupakan penerimaan kotor (belum dikurangi biaya yang dikeluarkan) yang diperoleh perusahaan dalam satu kali proses produksi, penerimaan dalam hal ini merupakan hasil kali jumlah produk dengan harga produk per unit. Total biaya merupakan biaya yang dikeluarkan selama melakukan proses produksi, baik biaya eksplisit maupun biaya implisit. Laporan keuangan merupakan indikator untuk satu periode, untuk menganalisis perusahaan digunakan analisis rasio. Keampuhan analisis dengan perangkat rasio keuangan disebabkan oleh sifatnya yang mampu mengatasi kelemahan analisis yang hanya didasarkan pada perbedaan nilai uang saja, yang kadang-kadang tidak saja membingungkan tetapi juga menyesatkan. ${ }^{19}$

\subsection{Return on Asset}

Return on Asset (ROA) merupakan salah satu rasio profitabilitas, dalam analisis laporan keuangan rasio ini paling sering digunakan karena mampu

\footnotetext{
${ }^{17}$ Bactiar Usman, "Analisis Rasio Keuangan Dalam Memprediksi Perubahan Laba Pada Bank Bank di Indonesia”, Media Riset Bisnis dan Manajemen. Vol.3, No.1, April, 2003, hal 59-74.

18 Suwiknyo, Dwi. Analisis Laporan Keuangan Perbankan Syariah. (yogyakarta: Pustaka Pelajar, 2010), hal 186.

19 Istis Baroh, "Analisis Profitabilitas Agroindustri Kripik Pisang (Studi Kasus Kota Lumajang)”, Vol. 1. No. 2, Juni, 2015, hal 5-6.
} 
menunjukkan keberhasilan perusahaan menghasilkan keuntungan. Return on Asset mampu mengukur kemampuan perusahaan menghasilkan keuntungan pada masa lampau untuk kemudian diproyeksikan di masa yang akan datang. Asset atau aktiva yang di maksud adalah seluruh harta perusahaan yang diperoleh dari modal sendiri atau modal asing yang telah diubah perusahaan menjadi aktiva untuk digunakan oleh perusahaan. Rasio laba bersih terhadap total aktiva untuk mengukur pengembalian atas total aktiva setelah bunga dan pajak.

Istilah Return on Asset dengan Net Earning Power Ratio (Rate of Return on Investment atau Return on Investment) yaitu kemampuan dari modal yang diinvestasikan dalam keseluruhan aktiva untuk menghasilkan keuntungan sesudah pajak. Perhitungan Return on Asset untuk pengembalian atas total aktiva dihitung dengan cara membandingkan laba bersih yang tersedia untuk pemegang saham biasa dengan total aktiva, dapat dihitung dengan rumus yaitu:

\section{Return on Asset $(\mathrm{ROA})=$ Laba bersih / Total aktiva}

Semakin besar nilai Return on Asset menunjukkan kinerja perusahaan yang semakin baik pula, karena tingkat pengembalian investasi semakin besar, nilai ini mencerminkan pengembalian perusahaan dari seluruh aktiva atau pendanaan yang diberikan pada perusahaan.

Dari pemaparan di atas dapat disimpulakan bahwa Return on Asset adalah rasio yang menunjukkan seberapa besar laba bersih yang diperoleh perusahaan. Karena itu digunakan angka setelah pajak, dengan demikian rasio ini menghubungkan keuntungan yang diperoleh dari operasi perusahaan dengan jumlah aktiva yang digunakan. Faktor yang mempengaruhi Rasio Return on Asset yaitu rasio perputaran kas, perputaran piutang dan perputaran persediaan.

Indikator profitabilitas yang berdasarkan Return on Asset mempunyai keunggulan yaitu:

1) Sebagai salah satu kegunaan prinsip sifat yang menyeluruh. Apabila perusahaan sudah menjalankan praktik akutansi yang baik maka manajemen dengan menggunakan teknik analisa Return on Investmnet dapat mengukur efisiensi penggunaan modal bekerja, efisiensi produk dan efisiensi bagian penjualan.

2) Apabila perusahaan dapat mempunyai data industri sehingga dapat diperoleh rasio industri, maka dengan analisis Return on Investment dapat dibandingkan efisiensi penggunaan modal pada perusahaannya dengan perusahaan yang sejenis. Sehingga dapat diketahui apakah perusahaan berada dibawah, sama atau diatas rata-rata. Dengan demikian akan dapat diketahui dimana kelemahannya dana apa yang sudah kuat pada perusahaan tersebut dibandingka perusahaan yang lain yang sejenis.

3) Analisis ini pun dapat digunakan untuk mengukur efisiensi tindakan yang dilakukan oleh bagian dengan mengalokasikan semua biaya dan modal ke dalam bagian yang bersangkutan.

4) Analisis ini juga dapat digunakan untuk mengukur profitabilitas dari masing-masing produk yang dihasilkan perusahaan. Dengan menggunakan produk sistem biaya produk yang baik. Modal dan biaya dapat dialpkasikan kepada berbagai produk yang dihasilkan oleh perusahaan yang bersangkutan, sehingga dengan demikian akan dihitung dari masing-masing produk. 
5) Return on Investment atau Return on Asset selain berguna untuk keperluan kontrol juga berguna untuk keperluan perencanaan. Misalnya Return on Investment dapat digunakan sebagai dasar untuk pengambilan keputusan kalau perusahaan akan mengadakan perluasan.

Selain mempunyai indikator keunggulan Return on Asset juga mempunyai indikator kelemahan yaitu:

1) Kesukarannya dalam membandingkan rate of return suatu perusahaan dengan perusahaan lain sejenis mengingat bahwa kadang-kadang praktek akuntasi yang digunakan oleh masing-masing perusahaan tersebut berbeda-beda. Perbedaan metode dalam penilaian berbagai aktiva antara perusahaan yang satu dengan perusahaan yang lain, perbandingan tersebut akan dapat memberi gambaran yang salah. Ada berbagai metode penilaian inventori yang digunakan akan berpengaruh terhadap besarnya nilai inventory dan yang selanjutnya akan berpengaruh terhadap jumlah aktiva.

2) Kelemahan lain dari teknik analisa ini adalah terletak pada adanya fluktuasi nilai dari uang suatu mesin atau pelengkap tertentu dibeli dalam keadaan inflasi nilainya berbeda kalau dibeli pada waktu tidak adanya inflasi, dan hal ini akan berpengaruh dalam menghitung laba.

3) Dengan menggunakan analisa rate of return saja tidak akan dapat digunakan untuk mengadakan perbandingan antara dua perusahaan atau lebih dengan mendapatkan kesimpulan yang memuaskan.

\section{Korelasi antara Penerapan Akad Mudharabah dan Profitabilitas Bank Syariah Mandiri}

Perkembangan perekonomian nasional yang mengalami perubahan sangat cepat sehingga membutuhkan perbankan naisonal yang tangguh maka diperlukan adanya pengaturan kegiatan lembaga perbankan. Undang-Undang perbankan No.10 tahun 1998 tentang perbankan berdasarkan prinsip syariah menyebutkan bahwa bank dapat memberikan kredit atau pembiayaan dengan imbalan atau pembagian hasil keuntungan. Kegiatan Bank Syariah Mandiri dalam pembiayaan mudharabah telah diatur dalam peraturan Bank Indonesia No 6/24/PBI/2004 pasal 36 mengenai kegiatan usaha yang meliputi penghimpunan dana dari masyarakat dan juga melakukan penyaluran dana. Pasal 36 butir b peraturan bank Indonesia No.6/24/PBI/2004 menyebutkan bahwa kegiatan menyalurkan dana malalui prinsip jual beli, prinsip sewa menyewa, prinsip pinjam meminjam dan prinsip bagi hasil, prinsip bagi hasil tersebut terdiri dari mudharabah dan musyarakah.

Pembiayaan mudharabah di Bank Syariah Mandiri dimana bank menyediakan seluruh modal kerja yang dibutuhkan nasabah ditanggung oleh bank sedangkan keuntungan dibagi sesuai dengan nisbah bagi hasil yang telah disepakati, nasabah mengajukan permohonan pembiayaan pada pihak bank untuk memberikan modal suatu proyek atau usaha yang akan dilakukan oleh nasabah dengan kesepakatan bagi hasil sesuai kesepakan oleh kedua pihak antara bank dan nasabah, sedangkan kerugian dari usaha atau proyek tersebut akan ditanggung oleh bank. 


\section{Gambar 5.1. Skema Permohonan Pembiayaan Mudharabah di Bank Syariah Mandiri}

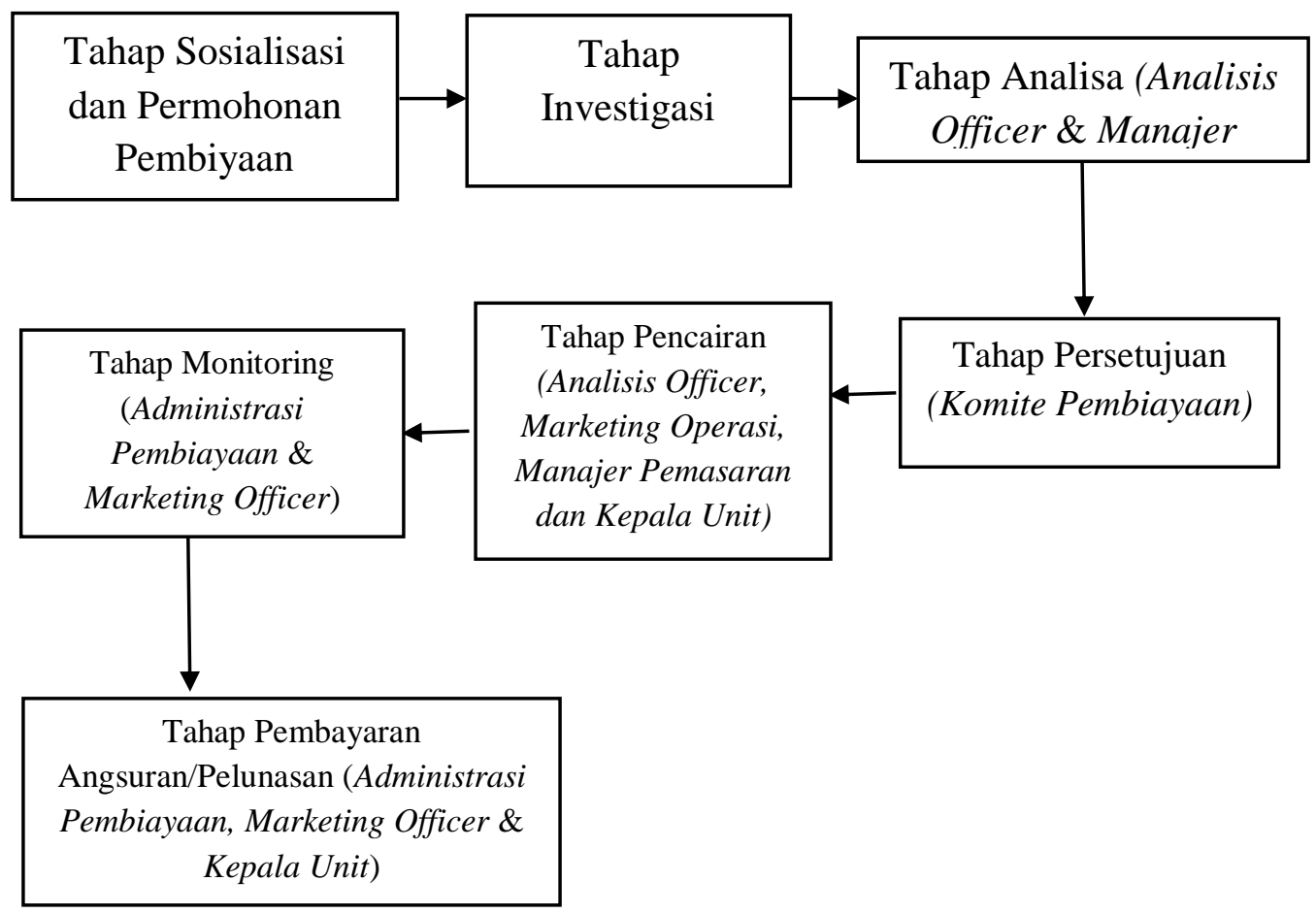

5.1.Korelasi antara Pelaksanaan Mudharabah dengan Profitabilitas pada Bank Syariah Mandiri

Koefisien Determinasi $\left(\mathbf{R}^{\mathbf{2}}\right)$

Besarnya koefisien determinasi $\left(\mathrm{R}^{2}\right)$ menunjukkan sampai seberapa besar perbandingan perubahan variabel independen terhadap variabel dependen. Semakin besar nilai koefisien determinasi menunjukkan bahwa variabel independen yang digunakan mempunyai korelasi variabel dependen.

Tabel 5.1. Uji Determinasi Model Summary

\begin{tabular}{|c|c|c|l|l|}
\hline Model & $\mathrm{R}$ & $\begin{array}{c}\mathrm{R} \\
\text { Square }\end{array}$ & $\begin{array}{l}\text { Adjusted } \\
\text { Square }\end{array}$ & $\begin{array}{l}\mathrm{R} \\
\text { Std. Error of the } \\
\text { Estimate }\end{array}$ \\
\hline 1 &, $928^{\mathrm{a}}$ &, 862 &, 816 &, 003 \\
\hline
\end{tabular}

a. Predictors: (Constant), PENDAPATAN_MUDHARABAH

Dari output tabel 4.2 ditehaui koefisien determinasi (R Square) sebesar 0,862, untuk menghitung besarnya korelasi antara pendapatan mudharabah dengan profitabilitas menggunakan angka R Square (angka korelasi yang dikuadratkan). Angka R Square disebut sebagai koefisien determinasi. Dari tabel di atas menjelaskan besarnya nilai korelasi atau hubungan $(\mathrm{R})$ yaitu sebesar 0,928 . Dari output tersebut dapat diperoleh koefisien determinasi (R Square) sebesar 0,862, yaitu mengandung pengertian bahwa korelasi antara variabel bebas mudharabah dengan variabel terikat profitabilitas adalah sebesar 86,2\%. Angka tersebut mengandung arti bahwa mudharabah mempunyai korelasi dengan profitabilitas 
sebesar 0,862 sedangkan sisanya $(100 \%-86,2=13,8 \%)$ mempunyai korelasi dengan variabel lain di luar model regresi ini. Besarnya korelasi variabel lain ini di sebut error. Maka semakin kecil nilai koefisien determinasi maka ini artinya korelasi variabel bebas terhadap variabel terikat semakin lemah, sebaliknya jika nilai R Square semakin mendekati 1 maka korelasi tersebut akan semakin kuat.

Dasar Pengambilan Keputusan dalam Uji Regresi Sederhana adalah berdasarkan nilai signifikansi dari tabel koefisien diperoleh nilai signifikan sebesar 0,023 < 0,05 yang berarti signifikan. Dengan demikian dapat disimpulkan bahwa variabel mudharabah (X) mempunyai korelasi dengan variabel profitabilitas (Y).

\section{Kesimpulan}

Berdasarkan analisis dan pembahasan yang telah diuraikan pada bab-bab sebelumnya dan juga berdasarkan pada hasil penelitian yang telah dibahas pada bab empat dengan bantuan regresi sederhana dan hasil wawancara dengan pihak bank. Berdasarkan hasil penelitian tersebut maka dapat ditarik kesimpulan sebagai berikut: pertama, pelaksanaan pembiayaan mudharabah pada Bank Syariah Mandiri pada prinsipnya mengedepankan saling percaya antara nasabah dengan pihak Bank Syariah Mandiri hal ini dpaat diketahui dari akad dan prosedur pembiayaan dilakukan beberapa tahap yaitu, tahap sosialisasi dan permohonan, tahap investigasi, tahap analisa, tahap persetujuan, tahap pencairan, tahap monitoring, tahap angsuran dan tahap perhitungan bagi hasil. Kedua, berdasarkan hasil pengujian data maka korelasi antara pelaksanaan mudharabah pada bank syariah mandiri sama dengan pelaksanaan pembiayaan lainnya. Hasil pengolahan uji data menunjukkan berpengaruh positif dan signifikan yang berarti variabel independen Mudharabah mempunyai korelasi positif dan signifikan dengan variabel dependen profitabilitas Return on Asset. Artinya bahwa pembiayaan mudharabah mempunyai korelasi yang positif dan signifikan dengan profitabilitas pada bank syariah mandiri.

\section{Daftar Pustaka}

Acarya. 2007. Akad \& Produk Bank Syariah. Jakarta. PT. Raja Grafindo Prsada. Antonio, M Syafi'I. 2001. Bank Syariah Teori dan Praktek Jakarta: Gema Insani. . 1999. Bank Syariah Suatu Pengenalan Umum. Jakarta: Tazkia Institute dan BI, Cet. ke-I.

Arthesa Ade dan Handima Edia.2006. Bank dan Lembaga Keuangan Bukan Bank. Jakarta. PT. Indeks.

Brigham, Eugene \& F Houston Joel, Manajemen Keuangan II. 2001 Jakarta.

Salemba Empat.

Darmawan, Deni. 2013. Metode Kuantitatif. Bandung. Rema Rosdakarya.

Ghozali, Imam. 2009. Ekonometrika-Teori, Konsep dan Aplikasi dengan SPSS 17, Semarang. Badan Penerbit Diponegoro

Faisal, M Abdullah. 2001. Dasar-Dasar Manajemen Keuangan. Malang. Universitas Muhammadiyah Malang PRESS. 
Kasmir dan Jakfar. 2003. Studi Kelayakan Bisnis. Jakarta. Kencana Prenada Media Group.

A Karim, Adiwarman. 2010. Bank Islam Analisis Fiqh dan Keuangan. Jakarta: PT. RajaGrafindo Persada

Kasmir. 2002. Manajemen Prbankan. Jakarta. PT. RajaGrafindo Persada.

Kuncoro. 2002. Manajemen Perbankan dan Aplikasi. Yogyakarta. BPEE. Cet. I

Muhammad. 2001. Teknik Perhitungan Bagi hasil di Bank Syariah. Yogyakarta: UII Press.

Nasroen Haroen. 2000. Fiqh Muamalah. Jakarta: Gaya Media Pratama.

Nurhasanah, Neneng. 2015. Mudharabah Dalam Teori dan Praktik. bandung.. PT. Refika Aditama.

Riyanto, Bambang. Dasar-Dasar Pembelajaran Perusahaan. Yogyakarta Buku Empat, Cetakan ketujuh BPFE.

Rivai, Veithzal. 2008. Islamic Financial Mnagement. Jakarta. PT. RajaGrafindo Persada.

Rivai, Veithzal. 2009. Manajemen Sumber Daya Manusia Untuk Perusahaan Dari Teori ke Praktik. Jakarta. Raja Grafindo Persada.

Suwiknyo, Dwi. 2010. Analisis Laporan Keuangan Perbankan Syariah. Yogyakarta. Pustaka Pelajar

Syahyunana. 2004. Manajemen Keuangan. Medan. USU PRESS.

Seed, Abdullah. 2004. Bank Islam dan Bunga. Yogyakarta. Pustaka Pelajar. . 2004. Menyoal Bank Syariah. Jakarta. Paramadina.

Suharsimi. A. 2010. Prosedur Penelitian Suatu Pendekatan Praktik. Jakarta. Rineka Cipta.

Sugiyono. 2009. Metode Penelitian Kuantitatif \& Kualitatif. Jakarta. Alfabeta.

Sumitro, Warkum. 2004. Asas-Asas Perbankan Islam Dan Lembaga-Lembaga Terkait. Jakarta: PT. Grafindo Persada.

Triandaru, Sigit \& Budisantoso, Totok. 2006. Bank dan Lembaga Keuangan Lain. Jakarta. Salemba Empat Cet. II.

Umar. M. Capra. 2005. Islam dan Tantangan Ekonomi Islam Kontemporer. Jakarta. Gema Insani

2001. Masa Depan Ilmu Ekonomi: Sebuah Tinjauan Islami. Jakarta. Gema Insani

Ulum, Ihyaul \& Juanda, Ahmad. 2016. Metodelogi Penelitian Akutansi Klinik Skripsi, Ed II:, Malang: Adtiya Media Publishing

Usanti, Trisadi P, dan Shomad Abdullah. 2013. Transaksi Bank Syariah. Jakarta: Bumi Aksara

Van Horne, James C. Dan M.Jhon Wachowicz, 2005. Prinsip-Prinsip Manajemen keuangan, Diterjemahkan oleh Aria Farahmita, Amanugrani, dan Taufik Hendrawan, edisis kedua belas, PT.Salemba Empat, Buku Satu, Jakarta.

Wild, John, K.R. Subramanyam, dan Robert F. Halsey. 2005. Analisis Laporan Keuangan. VIII, Jakarta, Buku Dua Alih Bahasa: Yanivi dan Nurwahyu: Salemba Empat.

Warsono. 2003. Manajemen Keuangan Buku I. Malang. Bayumedina. Cet III. 